\title{
Enterprise Risk Management to Minimizing Financial Distress Condition Using Analytical Hierarchy Process Method in PT. XYZ
}

\author{
Ervie Nur Afifa Mukhlis and Sylviana Maya Damayanti
}

\section{ABSTRACT}

PT. XYZ as one of telecommunications infrastructure providers that suffered losses gave a strong signal that the company was experiencing financial distress. Altman $z$-score is used to know the condition of the company. The result of Altman z-score analysis company has to further analyze the cause of financial distress. To prevent the company from bankruptcy risk, we cannot only focus on the financial aspect but also from various aspect. Enterprise risk management is used as a tool to identify what risks that could lead companies to experience financial distress and which risk should be mitigated. Risk assessment in this study using the analytic hierarchy process to check and reduce the expert inconsistency. After conducting risk management process, monitoring and review as the final step and implementation of this study. The result from this study is most of the risk are classified into high and medium risk can be mitigate by reduce or transfer the risk depend on the most suitable risk treatment. There are risks that classified as low risk, environment risk and promotion risk.

Keywords: Altman Z-Score; Analytical Hierarchy Process; Enterprise Risk Management; Financial Distress.

\section{INTRODUCTION}

As stated in the preamble of the Indonesian 1945 constitution article $33 \mathrm{PT}$. XYZ as SOE has to promoting the welfare of all the people of Indonesia. SOE as an extension of the of the government expected to generate profits for the nation and also required to be able to be able to constantly improve the performance in order to avoid financial failure that impact on a state revenue.

TABLE I: STATE-OWNEd ENTERPRISE PROFIT PERFORMANCE

\begin{tabular}{ccccccc}
\hline \hline \multirow{2}{*}{$\begin{array}{c}\text { Profit } \\
\text { Performance }\end{array}$} & \multicolumn{2}{c}{$\begin{array}{c}\text { State-owned } \\
\text { enterprise }\end{array}$} & \multicolumn{2}{c}{$\begin{array}{c}\text { Subsidiary } \\
\text { entity }\end{array}$} & \multicolumn{2}{c}{$\begin{array}{c}\text { Sub-subsidiary } \\
\text { entity }\end{array}$} \\
\cline { 2 - 7 } & Total & $(\%)$ & Total & $(\%)$ & Total & $(\%)$ \\
\hline $\begin{array}{c}\text { Stable profit } \\
\text { performance }\end{array}$ & 81 & 71 & 202 & 59 & 126 & 40 \\
$\begin{array}{c}\text { Unstable profit } \\
\text { performance }\end{array}$ & 29 & 25 & 101 & 30 & 114 & 36 \\
$\begin{array}{c}\text { Loss performance } \\
\text { Data not available }\end{array}$ & 4 & 4 & 24 & 7 & 39 & 12 \\
Total Company & 114 & 0 & 14 & 4 & 38 & 12 \\
\hline \hline
\end{tabular}

Based on the company's profit appraisal data in the table above in 2014-2018, 25\% SOE has unstable profit performance and $4 \%$ is suffered loss [1]. Besides that, with the development of telecommunications in line with the increasing human need to communicate digitally, it is important to well-build the infrastructure.

PT. XYZ as one of telecommunications infrastructure providers that suffered losses gave a strong signal that the company was experiencing financial distress. We use the
Altman Z-score to predict financial condition. To prevent the company from bankruptcy risk, we cannot only focus on the financial aspect but also from various aspect such as operation, marketing, human resource and etc. Enterprise risk management is used as a tool to identify what risks that could lead companies to experience financial distress and which risk should be mitigated. So that with good risk handling, likelihood and impact from the risk could be avoided or decreased. The tools that we used to asses possible risk is analytical hierarchy process

\section{A. Analysis of Company Business Situation}

We can analyze company business situation through external and internal analysis. In this study, the external analysis will discuss through PEST analysis. Meanwhile, the internal analysis will discuss financial condition of the company through Altman Z-Score analysis conducted by reviewing the annual report from 2015-2019 and discuss with the expert with intention of finding out what problem faced by the company.

\section{1) PEST Analysis}

PEST Analysis is a management method whereby an organization can assess major external factors that influence its operation in order to be more competitive in the market and make a strategic planning to maximize the organization ability to capitalize on current condition, to be forewarned of, and better prepared for imminent changes [2]. 


\section{a) Politics/Legal}

Companies and governments try to influence one another [2]. As SEO, PT.XYZ is also relatively burdened with various regulations from government through related ministry regulation such as bureaucratic reform program, defense industry policy, policies related to industry revolution 4.0, and domestic component level policies especially for telecommunication product. Often times these regulations make the company difficult to make decisions independently. Also, the political uncertainty and the government intervention make the company unable follows the market changes dynamically.

\section{b) Economics}

This segment related to the economic condition where the company competed. In general, company will look for the segment with stable economic and has potential growth [2]. The projected Indonesian GDP growth is predicted to decreased in 2020. While from the three previous year Indonesian service-based sectors GDP grow faster. Yet, it predicted to decreased in 2020 due to pandemic situation.

President of Indonesia push for infrastructure development should put more emphasis to private sector participation, given the limit on government fiscal capacity. The industrial revolution 4.0 encouraged companies to adjust the development of their production and manufacturing to improve Indonesia's industrial competitiveness. Related to that, electronic industry is become one of the priorities industrial sector. As ICT company based on electronic, it could be a good business prospect for PT.XYZ. However, the declining of GDP will also affect company's business environment.

\section{c) Social and Technological}

Sociocultural analysis is related to people attitude, behavior and cultural value [2]. Nowadays, people are accustomed to using mobile phones and internet in their activities that are involved with creating the knowledge and translating it into new output, product, processes and material. Social and demographic factors projected will continue to increase 238,5 million in 2010 to 305,6 million in 2035.

Internet usage in Indonesia has increased in recent years. The number of Internet users in Indonesia in 2017 has reached 143,26 million and increased to 171,18 in 2018. And acting and the number of internet users to the total population is about $64,8 \%$ [3]. As one of the companies in the field of ICT, the situation is seen as a great business prospect for the company to make smart innovation that can address all the needs arising from change in behavior and culture of telecommunication in the country.

\section{2) Financial Distress}

Financial Distress is the condition where the company obligations are higher than their assets or when the company declared unable to pay their debt. Financial distress can be described from two extreme points, that is short term financial difficulties to insolvable liquidity [4]. When the company's financial condition is un-healthy or facing crisis, it can be said that the company is experiencing financial distress that can lead into bankruptcy. Below is the basic model of bankruptcy or trinity of causes of financial distress [5].

\section{a) Neoclassical Model}

In this case bankruptcy occurs if the asset location is improper and the company has the wrong asset composition. Which can be assessed balance sheet and income statement. For example, profitability and liability ratio. During the five years current ratio of PT.XYZ was below 1 and tend to decrease from year to year, shows the company is not able to fully utilize its assets.

TABLE II: PT.XYZ CURRENT RATIO

\begin{tabular}{cccccc}
\multicolumn{6}{c}{ TABLE II: PT.XYZ CURRENT RATIO } \\
\hline \hline Years & 2015 & 2016 & 2017 & 2018 & 2019 \\
\hline Current Ratio & $78.42 \%$ & $45.87 \%$ & $67.98 \%$ & $65.75 \%$ & $58.89 \%$ \\
\hline \hline
\end{tabular}

\section{b) Financial Model}

In this model, asset composition is good enough but not with financial structure with liquidity constraints. Bad relationship with capital market and inherited capital structure is the main trigger. The model estimated financial distress through financial and performance indicators in the table below:

TABLE III: COMPARISON OF FINANCIAL RATIO BETWEEN PT.XYZ AND

\begin{tabular}{ccc}
\multicolumn{3}{c}{ AVERAGE INDUSTRY } \\
\hline \hline Ratio & PT.XYZ & Average Industry \\
\hline Current Ratio (\%) & 78 & 119.8 \\
Inventory Turnover (days) & 313.0 & 59.2 \\
Collection Periods (days) & 317.0 & 71.2 \\
Sales to average asset (\%) & 17.8 & 64.2 \\
Net Profit Margin (\%) & 1.1 & 9.4 \\
Operating cashflow to sales (\%) & -47.5 & 11.1 \\
ROA (\%) & -25.1 & 3.3 \\
ROE (\%) & -104.0 & 9.5 \\
ROI (\%) & -20.2 & 8.4 \\
DER (X) & 4.5 & 2.5 \\
\hline \hline
\end{tabular}

Table V shows that PT.XYZ is underperform the average industry of Indonesian SOE's strategic industry.

\section{c) Corporate Governance Model}

On this model of bankruptcy, the company is already having good assets composition and financial structures but poorly managed. This inefficiency drives the company being out of the market as a consequences of unsolved corporate governance issue. Indonesia GCG ranking is always below Singapore, Malaysia and Thailand and its corruption index still ranks 80-90 of 190 countries [6]. The government through the Ministry of SOE has been aggressively implementing GCG since October 2019. It was emphasized that SOE as an agent of development must be able to produce goods and services that improve people's welfare, encourage economic growth, create jobs and reduce poverty.

\section{3) Altman Z-Score}

There is various previous study have been carried out to obtain combination of financial ratio to be an ideal analysis model. One of which is a model conducted by Altman that predict the bankruptcy of a company that grouped into five, including Liquidity, Profitability, Leverage, Solvency, and Activity. Based on the multiple discriminant analysis methods, the coefficients of the five financial ratios determined by the sum and multiplications of each coefficient then generated a multivariate value called z-score by Altman. Altman Z-score is divided into three kinds of discriminant functions, [7]. including: 


\section{a) Original Z-Score 1968 (for a public manufacturer)}

Altman produced the first bankruptcy model. The equation of this model is:

$Z=1,2 X 1+1,4 X 2+3,3 X 3+0,64 X 4+0,999 X 5$

where:

$$
\begin{aligned}
& \mathrm{Z}=\text { Bankruptcy Index } \\
& \mathrm{X} 1=\frac{\text { Working Capital }}{\text { Total Assets }} \\
& \mathrm{X} 2=\frac{\text { Retained Earning }}{\text { Total Assets }} \\
& \mathrm{X} 3=\frac{\text { Earning Before Interest and Taxes }}{\text { Total Assets }} \\
& \mathrm{X} 4=\frac{\text { Market Value of Equity }}{\text { Book Value of Total Debt }} \\
& \mathrm{X} 5=\frac{\text { Sales }}{\text { Total Assets }}
\end{aligned}
$$

\section{b) Altman Z-Score 1983 (for private manufacturer)}

In 1983, Altman developed a model for a private manufacturing company. The equation difference is the coefficient for $\mathrm{X} 1, \mathrm{X} 2$ and $\mathrm{X} 3$. The $\mathrm{X} 4$ variable for this function uses the book value of stockholder equity obtained from divided the book value of equity by total liabilities because it does not have a market value of equity. The equation of this model is:

$$
\begin{aligned}
& Z=0,717 X 1+0,847 X 2+3,107 X 3+0,42 X 4+ \\
& 0,998 X 5
\end{aligned}
$$

c) Altman Z-Score 1955 (for private general firm/nonmanufacturing firm)

The third model developed by Altman was used to predict the bankruptcy of non-manufacturing companies such as small businesses, retail, sales, wholesalers, and service sectors. This Model eliminates the value of X5 (sales to total assets) because it always changes significantly in the industry. So that the equation will be as follow:

$$
Z=6,56 X 1+3,26 X 2+6,72 X 3+1,52 X 4
$$

\section{d) Altman Z-Score for non-manufacturers and emerging market}

The next modification of the Z-Score model assesses the characteristics and accuracy of a model without X5 sales/total assets. We do this in order to minimize the potential industry effect that is more likely to take place when such an industrysensitive variable as asset turnover is included. The book value of equity was used for $\mathrm{X} 4$ in this case. All of the coefficients for variables $\mathrm{X} 1$ to $\mathrm{X} 4$ are different from the original Z-Score model, as are the group means and cutoff scores. In the emerging market model, the model added a constant term of +3.25 so as to standardize the score with a score of zero adequate to a default rated bond. This model is believed more appropriate for nonmanufacturers than is the original Z-Score model. Of course, models developed for specific industries (e.g., retailers, telecoms, airlines, etc.) are an even better method for assessing distress potential of likeindustry firms. The classification accuracy results are identical to the revised ( $Z^{\prime}$-Score) five-variable model. The new Z-Score model is:

$$
Z=3,25+6,56 X 1+3,26 X 2+6,72 X 3+1,05 X 4
$$

\begin{tabular}{|c|c|c|c|c|c|}
\hline & 2015 & 2016 & 2017 & 2018 & 2019 \\
\hline $\mathrm{X} 1$ & $(0.14)$ & $(0.41)$ & $(0.27)$ & $(0.28)$ & $(0.24)$ \\
\hline Current Assets & $976,330,474,938$ & $478,709,865,361$ & $1,158,602,638,938$ & $976,779,557,285$ & $481,814,021,090$ \\
\hline Current Liabilities & $1,244,939,256,409$ & $1,043,514,565,791$ & $1,704,424,565,445$ & $1,485,561,816,863$ & $818,105,452,060$ \\
\hline Total Assets & $1,869,763,721,691$ & $1,366,832,637,096$ & $2,026,983,628,127$ & $1,829,674,439,105$ & $1,393,342,534,992$ \\
\hline $\mathrm{X} 2$ & $(0.20)$ & $(0.39)$ & $(0.42)$ & $(0.46)$ & $(0.68)$ \\
\hline Retained Earning & $(375,602,732,345)$ & $(537,543,121,821)$ & $(852,894,718,939)$ & $(846,524,360,508)$ & $(942,161,373,014)$ \\
\hline Total Assets & $1,869,763,721,691$ & $1,366,832,637,096$ & $2,026,983,628,127$ & $1,829,674,439,105$ & $1,393,342,534,992$ \\
\hline X3 & $(0.06)$ & $(0.16)$ & 0.04 & 0.05 & $(0.06)$ \\
\hline EBIT & $(110,446,914,994)$ & $(219,021,693,103)$ & $79,415,425,080$ & $99,819,003,552$ & $(86,836,586,274)$ \\
\hline Total Assets & $1,869,763,721,691$ & $1,366,832,637,096$ & $2,026,983,628,127$ & $1,829,674,439,105$ & $1,393,342,534,992$ \\
\hline $\mathrm{X} 4$ & 0.39 & 0.16 & 0.12 & 0.14 & $(0.16)$ \\
\hline BV of Equity & $524,306,346,758$ & $190,741,057,529$ & $214,282,572,530$ & $221,567,922,155$ & $(268,637,240,308)$ \\
\hline Total Assets & $1,869,763,721,691$ & $1,366,832,637,096$ & $2,026,983,628,127$ & $1,829,674,439,105$ & $1,393,342,534,992$ \\
\hline Total Liabilities & $1,345,457,374,933$ & $1,176,091,579,567$ & $1,812,701,055,597$ & $1,608,106,516,950$ & $1,661,979,775,300$ \\
\hline Total Liabilities & $1,345,457,374,933$ & $1,176,091,579,567$ & $1,812,701,055,597$ & $1,608,106,516,950$ & $1,661,979,775,300$ \\
\hline Z-Score & 1.81 & $(4.49)$ & $(2.48)$ & $(2.54)$ & $(4.13)$ \\
\hline & - & Distress Zone & Distress Zone & Distress Zone & Distress Zone \\
\hline
\end{tabular}

\section{4) Z-scores Cut-off}

The $\mathrm{Z}$ value is an index of overall function of multiple discriminant analysis. According to Altman, there are cut-off numbers of $\mathrm{Z}$ values that can explain whether the company will fail or not in the future and he divides it into three categories, as in Table IV.

TABLE IV: CUT-OFF NUMBER OF Z-SCORE

\begin{tabular}{ccccc}
\hline \hline $\begin{array}{c}\text { Zones of } \\
\text { Discrimination }\end{array}$ & $\begin{array}{c}\text { Z-Score (public } \\
\text { manufacturer) }\end{array}$ & $\begin{array}{c}\text { Z-Score } \\
\text { (Private } \\
\text { Manufacturer) }\end{array}$ & $\begin{array}{c}\text { Z-Score (Private } \\
\text { General Firm / non- } \\
\text { manufacturing Firm) }\end{array}$ & $\begin{array}{c}\text { Z-Score (Non- } \\
\text { Manufacturers and in } \\
\text { Emerging Markets) }\end{array}$ \\
\hline Safe Zone & $\begin{array}{c}\mathrm{Z}>2,99 \\
\mathrm{Z}>2,9\end{array}$ & $\begin{array}{c}\mathrm{Z}>2,6 \\
1,23>\mathrm{Z}>2,9\end{array}$ \\
Grey Zone & $1,8>\mathrm{Z}>2,99$ & $1,23>\mathrm{Z}>2,9$ & $\mathrm{Z}<1,23$ & $\mathrm{Z}<0$ \\
Distress Zone & $\mathrm{Z}<1,8$ & $\mathrm{Z}<1,23$ & $\mathrm{Z}$ & \\
\hline \hline
\end{tabular}

TABLE V: ALTMAN Z-SCORE EQUATION RESULT 


\section{1) Altman Z-Score Equation of PT.XYZ}

After previously being known as a manufacturing company, in 1990 the operational activities of PT. XYZ gradually turned into service activities. Until 2015, the majority of PT XYZ's operational activities were service activities. So, the most suitable Altman z-score equation model is the (4) equation. The equation results as in Table V.

From the Table VII, we can conclude that the Z-Score for PT.XYZ for 2015-2019 period shows that the company is has a good score in 2015 but in 2016 to 2019 it is on the distress zone which can lead the company into bankruptcy. Even though the z-score had improved in 2016, the situation worsened again in the following years. Despite in 2014 the Zscore calculation result was above zero which meant that the company was in the safe zone. However, the company cannot be classified as a health financially company due to its negative EBIT and retained earnings.

\section{B. Business Issue}

Originally PT. XYZ was a major player and market leader which leads $60 \%$ of the total national market in the telecommunications infrastructure industry now experiencing the increasing of fierce competition due to openness business competition regulation by government. The company need a good financial condition to be able to compete. But in fact, in the last 4 years the company failed to reach their target as seen in the table below:

TABLE VI: TARGET AND REALIZATION

\begin{tabular}{|c|c|c|c|c|c|}
\hline & & 2016 & 2017 & 2018 & 2019 \\
\hline \multirow{2}{*}{$\begin{array}{c}\text { Reve } \\
\text { nue }\end{array}$} & Target & $\begin{array}{c}\mathrm{Rp} \\
1,000,000,000\end{array}$ & $\begin{array}{c}\mathrm{Rp} \\
1,588,295,616\end{array}$ & $\begin{array}{c}\mathrm{Rp} \\
2,000,285,401\end{array}$ & $\begin{array}{c}\mathrm{Rp} \\
1,571,389,393\end{array}$ \\
\hline & $\begin{array}{c}\text { Realizat } \\
\text { ion }\end{array}$ & $\begin{array}{c}\mathrm{Rp} \\
681,178,397\end{array}$ & $\underset{1,308,680,036}{\mathrm{Rp}}$ & $\begin{array}{c}\mathrm{Rp} \\
847,756,334\end{array}$ & $\underset{395,377,565}{\mathrm{Rp}}$ \\
\hline EBIT & $\begin{array}{l}\text { Target } \\
\text { Realizat } \\
\text { ion }\end{array}$ & $\begin{array}{c}\mathrm{Rp} \\
10,893,330 \\
\mathrm{Rp} \\
(219,021,693)\end{array}$ & $\begin{array}{c}\mathrm{Rp} \\
112,521,890 \\
\mathrm{Rp} \\
79,415,425\end{array}$ & $\begin{array}{c}\mathrm{Rp} \\
140,687,078 \\
\mathrm{Rp} \\
99,819,003\end{array}$ & $\begin{array}{c}\mathrm{Rp} \\
113,863,623 \\
\mathrm{Rp} \\
(86,836,586)\end{array}$ \\
\hline EAT & $\begin{array}{c}\text { Target } \\
\text { Realizat } \\
\text { ion }\end{array}$ & $\begin{array}{c}\mathrm{Rp} \\
3,016,600 \\
\mathrm{Rp} \\
(316,098,525)\end{array}$ & $\begin{array}{c}\mathrm{Rp} \\
4,299,179 \\
\mathrm{Rp} \\
6,610,955\end{array}$ & $\begin{array}{c}\mathrm{Rp} \\
10,059,065 \\
\mathrm{Rp} \\
462,656\end{array}$ & $\begin{array}{c}\mathrm{Rp} \\
8,313,324 \\
\mathrm{Rp} \\
(434,765,473)\end{array}$ \\
\hline
\end{tabular}

The bad financial condition may affect the company's sustainability. One of the tools that can help the company to monitor their financial condition is using a linear combination of four or five common business ratio that weighted by coefficient in Altman Z-score model. This tool facilitated the company to look which financial aspects has difficulties that need action. Besides that, the company could use this as a tool that gives information for instance warning system that could lead the company into bankruptcy if not solved immediately. The table below presents the company Altman Z-score:

TABLE VII: COMPANY'S ALTMAN Z-SCORE

\begin{tabular}{cccccc}
\hline \hline & 2015 & 2016 & 2017 & 2018 & 2019 \\
\hline Z-Score & 1.81 & $(4.49)$ & $(2.48)$ & $(2.54)$ & $(4.13)$ \\
& & Distress & Distress & Distress & Distress \\
& - & Zone & Zone & Zone & Zone \\
\hline \hline
\end{tabular}

As seen on the table above, PT.XYZ experienced bad condition reflected by the negative $\mathrm{Z}$-score value that means the company is in distress zone.

\section{DATA \& Methodology}

The data used in this research are primary and secondary data. Primary data is obtained through interview with expert also risk analysis and analytical hierarchy process questionnaire. While, secondary data obtained from company financial statement, website and annual report (2015-2019). However, literature review such as books, journals, previous study, websites and other related information are also used as other data and information.

After obtained the analysis of company business situation. From the result of Altman z-score analysis company have to further analyze the causes, how to mitigate and solve the financial problems that are being faced by the company through enterprise risk management. The company needs to conduct risk management process through four main process: Risk Identification, Risk Measurement or Risk Analysis, Risk Evaluation and Risk Mitigation or Risk Treatment. The risk identification as the first step conducted by discussing and combining the existing company risk profile with the COSO sample types of enterprise business risks with the various expert. Risk Measurement/risk analysis as the next step, conducted by expert judgement risk analysis questionnaire and analytical hierarchy process questionnaire. Risk evaluation then conducted after the risk measurement/risk analysis process by categorized risks by its importance and priority. The final step is Risk Mitigation/Risk Treatment is the important phase as in this step the company mitigate the possible risk occurred.

After conducting risk management process, monitoring and review as the final step and implementation of this study. This need to be done to ensure the appropriate action to mitigate the risk that affect the financial situation being experienced by the company.

\section{A. Analytical Hierarchy Process}

Analytic Hierarchy Process (AHP) is one of the general theories of measurement. It is utilized to determine proportion scales from both discrete and continuous paired comparison. These comparisons may be taken from real estimations or from a fundamental scale that reflects the relative strength of inclinations and sentiments. It has found extensive applications in multicriteria decision making, planning, arranging and asset allocation and conflict resolution [8]. The most advantage of AHP is its capability to check and diminish the inconsistency of expert judgement. While decreasing bias in the process of decision making, AHP provides group decision making through consensus by using the geometric mean of the personal judgement. AHP determines scales of values from pairwise comparisons in conjunction with ratings which appropriate for multi-objective, multi-criterion also multi-actor of final decision with several alternatives [9].

In utilizing the AHP to demonstrate an issue, we need hierarchy or an organized structure to represent that issue and pairwise comparisons to set up relations within the structure [8]. The hierarchy ought to be constructed so that components at the same level are of the same arrange of magnitude and must be able of being related to a few or all components within the following higher level. In a typical hierarchy, the top level reflects the overall objective (main focus) of the decision issue. The components/aspects which that influencing the decision are represented in the middle level. 
The lowest level comprises the options of the decision. This type of hierarchy gives an illustration of all the components influencing the decision and their relationship in a clear and simple way. The decision maker will start the prioritization method to determine the relative significance of the component in each level of hierarchy, once after the hierarchy has been constructed. Components in each level are pairwise compared with respect to their significance in making the decision under consideration. The comparison this scheme: How critical is component/aspect A when compared to B with regard to a particular aspect in the immediately higher level? For each level, beginning at the top of hierarchy and working down. Every component will be organized into homogenous grouping or cluster [10].

The decision maker can express his preferences between two aspects verbally or the descriptive preferences would then be translated into absolute numbers as follows:

TABLE VIII: THE FUNDAMENTAL OF AHP

\begin{tabular}{|c|c|c|}
\hline $\begin{array}{c}\text { Intensity } \\
\text { of } \\
\text { importance }\end{array}$ & Definition & Explanation \\
\hline 1 & Equal importance & $\begin{array}{l}\text { Both aspects contribute equally } \\
\text { important to the decision goal }\end{array}$ \\
\hline 3 & $\begin{array}{l}\text { Moderate importance } \\
\text { of one over another }\end{array}$ & $\begin{array}{l}\text { Judgements strongly favor one } \\
\text { aspect over another }\end{array}$ \\
\hline 5 & $\begin{array}{l}\text { Essential or strong } \\
\text { importance }\end{array}$ & $\begin{array}{l}\text { Judgements strongly favor one } \\
\text { aspect over another }\end{array}$ \\
\hline 7 & $\begin{array}{l}\text { Very strong } \\
\text { importance }\end{array}$ & $\begin{array}{l}\text { An aspect is strongly favored and its } \\
\text { dominance demonstrated in practice }\end{array}$ \\
\hline 9 & Extreme important & $\begin{array}{l}\text { The evidence favoring one aspect } \\
\text { over another is one of the highest } \\
\text { possible order of affirmation }\end{array}$ \\
\hline $2,4,6,8$ & $\begin{array}{l}\text { Intermediate value } \\
\text { between those two } \\
\text { adjacent judgements }\end{array}$ & If the compromise is needed \\
\hline Reciprocal & $\begin{aligned} \text { If } \mathrm{A} / \mathrm{B} & =9 \text { then } \\
\mathrm{B} / \mathrm{A} & =1 / 9\end{aligned}$ & \\
\hline
\end{tabular}

After the comparison matrices is formed, the next step is determining relative weights for the different elements. The relative weights of the components of each level with respect to a component in the adjacent upper level are computed as the components of the normalized eigenvector related with the largest eigenvalue of their comparison matrix. The composite weights of the decision alternatives are then determined by aggregating the weights through the hierarchy. This can be done by following a way from the top of the hierarchy to each alternative at the lowest level and multiplying the weights along each segments of the way. This aggregation will be resulted normalized vector of the overall weight of the alternative [10].

Common procedures are followed to acquire judgments on the relative importance of the sub-criteria and level of risk's likelihood and impact. In this research, level of likelihood and impact are divided into five level. Detail of risk level both for likelihood and impact are consecutively provided in table and table as follow:
TABLE IX: RISK LEVEL ALTERNATIVE FOR LIKELIHOOD

\begin{tabular}{|c|c|c|}
\hline \multicolumn{2}{|c|}{ Likelihood Score } & Description \\
\hline 1 & Very low & $\begin{array}{l}\text { Unlikely risks, which have a rare level of occurrence } \\
\text { such as less than } 10 \%\end{array}$ \\
\hline 2 & Low & $\begin{array}{c}\text { Seldom risks contains low probability of occurrence, } \\
\text { however, cannot yet excluded entirely }\end{array}$ \\
\hline 3 & Moderate & $\begin{array}{c}\text { Risk which have occasional 50:50 likelihood of harm } \\
\text { occurrence }\end{array}$ \\
\hline 4 & High & Risk that lies among $60 \% 80 \%$ chance of occurrence \\
\hline 5 & Very High & $\begin{array}{l}\text { A definite risk that has highest frequency (generally } \\
\text { more than } 80 \% \text { ) of reveal during certain project stages }\end{array}$ \\
\hline \multicolumn{3}{|c|}{ TABLE X: RISK LEVEL ALTERNATIVE FOR IMPACT } \\
\hline \multicolumn{2}{|c|}{ Impact Score } & Description \\
\hline 1 & $\begin{array}{l}\text { Un- } \\
\text { significant }\end{array}$ & $\begin{array}{c}\text { Doesn't have a significant impact on the company } \\
\text { (almost negligible) }\end{array}$ \\
\hline 2 & Minor & Has a little impact on the company \\
\hline 3 & Moderate & Has a significant risk for the company if it occurs \\
\hline 4 & Major & $\begin{array}{l}\text { Has a risk with significant consequences that could } \\
\text { cause a large number of losses if it occurs }\end{array}$ \\
\hline 5 & Catastrophic & $\begin{array}{l}\text { Having risks that can make the company completely } \\
\text { unproductive and produce nothing if it happens, so it } \\
\text { must be a top priority during risk management }\end{array}$ \\
\hline
\end{tabular}

In the real world, the use of AHP will be made much easier using a microcomputer implementation of the method such as Expert Choice Software which can eliminates tedious calculation by make structuring and modifying the hierarchy more simple and quicker. So, this research is using Expert Choice 11 for to help the author with the calculation.

\section{B. Analytical Hierarchy Process as The Risk Analysis}

Numerous techniques have been proposed for risk analysis and assessment from simple classical methods to fuzzy approaches like influence diagram method, sensitivity analysis technique, Monte Carlo simulation, decision analysis bearing decision matrices and decision trees, and the analytic hierarchy process were used to facilitate making decision under risky or uncertain situation. The main advantage of AHP is the capability to check and reduce the expert judgement inconsistency [9]. AHP as the risk analysis was used for several previous study such as safety risk assessment using analytic hierarchy process during planning and budgeting of construction projects [9], Risk assessment using the analytic hierarchy process while planning and prior to constructing wind project in Jordan [11] and project risk assessment using the Analytic Hierarchy Process [10].

\section{APPLICATION}

From the business issue that has been found in previous chapter, the author had come up with business solution which in author's point of view are feasible to be applied in PT. $\mathrm{XYZ}$. Enterprise risk management used as a tool to solve the financial distress problem that experienced by PT. XYZ. The integrated perspective of risk management would be structured in a process that includes a sequence of logical steps which is referred to the risk management process. This research used the risk management process by adopting ISO 31000:2009 framework which is commonly used by the company [12]. 


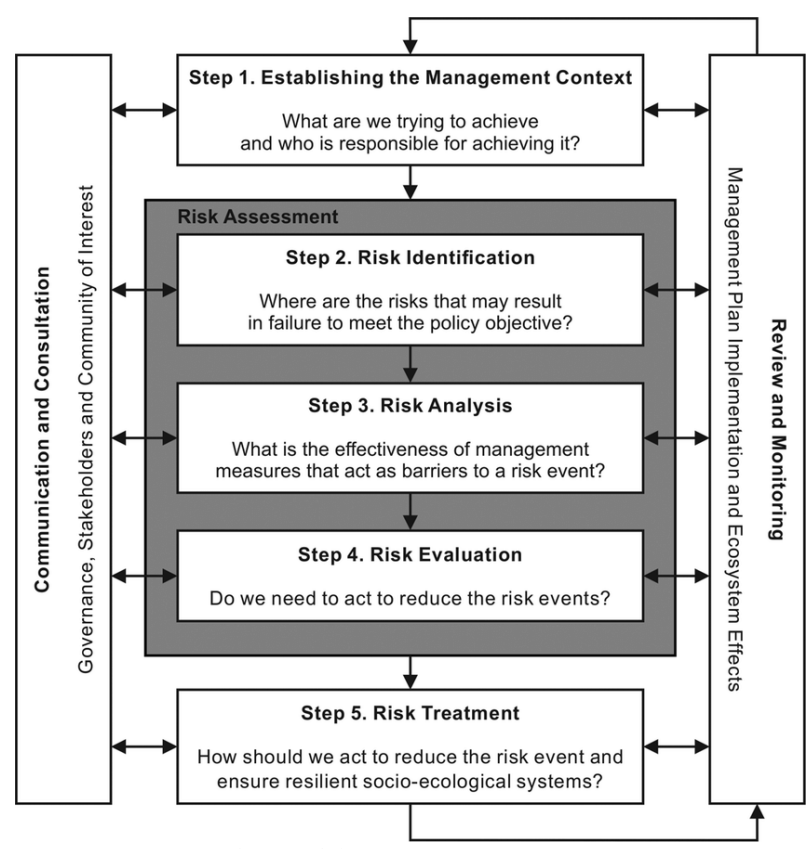

Fig. 1. Risk Management Process.

\section{A. Establish the Context}

On the risk management process, we need to establish the context to define the basic parameters inward which risks should be managed and to provide guidance for decision to more detailed risk management [13]. The most important thing here is what are the company trying to achieve and who is responsible for achieving it which is derived from company objectives. At this stage the involvement of stakeholders and decision makers is needed. On this research the company objective as the stated-owned enterprise is to become a company with good performance, viewed from financial, customer, internal process, organizational and human resource perspective can be achieved by strengthen financial condition of the company. So, the context of this risk management process is formulating the enterprise risk management in term of minimize financial distress.

\section{B. Risk Identification}

On this step we determine what things might happen that could affect the company objective, why and how those things might happen, also identify the risk if the company cannot achieve the established context. The risk identification process must be systematic and comprehensive, because risks that have not been properly identified cannot threaten, and can become a threat in the future without being able to mitigate the incident and impact the success of the company. This process requires a studied, deliberate approach to looking at potential risk in each area of operations and the identifying the more significant risks area that may impact each operation in a reasonable time period. We need to identify all risks whether under the control of the organization or not [14].

There are several approaches tools and techniques to identify risks which that brainstorming, Delhi technique, checklist analysis, cause and effect diagram, questionnaires, SWOT analysis, and expert judgments [15]. On this research risk identification obtained by using expert judgement through discussion with several decision maker in the company which high experienced in financial, risk, and project areas. The author discussed about sample types of enterprise business risk by $\mathrm{COSO}$ and compare with company risk profile owned by PT. XYZ. Then it will obtain as a new risk identification which more details depicted with company's risks hierarchy. that will be used to obtained next step of enterprise risk management process. Below is company's risk identification:
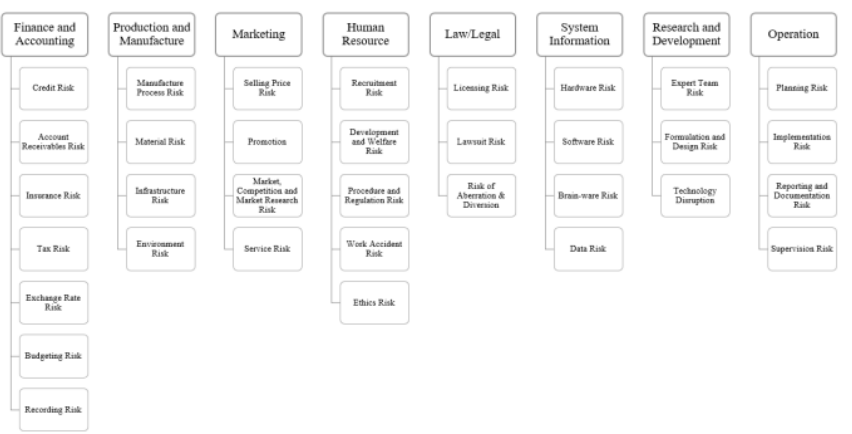

Fig. 2. Risk Identification.

\section{Risk Analysis}

The objective of risk analysis is to separate risk level and categorized the risk into minor risk until the major risks, also to provide data as the basis for risk evaluation and risk treatment. In this step we involve consideration for impact and likelihood for every risk. After that we analyzed each risk with combining its estimation of impact and likelihood for the risk control. In this research will use Analytical Hierarchy Process (AHP) method by Saaty to identify risk to minimize financial distress condition in PT.XYZ.

\section{1) Risk Analysis using AHP}

PT.XYZ is the company that experienced financial distress condition. The enterprise risk management will be conduct as the attempt to mitigate further risk which that bankruptcy. The risks will be analyzed by using AHP as the method of analyzing optimal enterprise risk management in order to minimize financial distress condition and aimed to determine the degree of identified risks in fig 2 as a consideration for decision maker and management to make a right decision. The steps to analyze risk on the PT.XYZ preceded by constructing hierarchy of AHP. Each category will be used to construct underlying hierarchy for specific risks, and the lowest level is the level which specified degree of risk will be used to analyze the level of likelihood and impact of the previous level of specific risk. The components of the normalized value of eigenvectors matrices are obtained by computing the various relative importance factors i.e. sub aspects and the level of risks which categorized into five levels: very high, high, moderate, low, and very low. The likelihood and impact of the various levels of risk given the outcome of the sub-aspects with respect to the overall goal.

To obtain the result of the analysis we need to conduct several steps. First is determining the possible risks related to PT. XYZ. Then, to simplify the process of analysis we designed the hierarchy model to grouping the risks which related by its category. This research has four level of hierarchy in which the weighted toward risk categories and risk factor will be measured. Pairwise comparison will be used as the weighted method for each matrix in each level. Level 1 is the decision goal, level 2 as the criteria (aspects), level 3 as the sub-criteria (sub-aspects) and level 4 as the alternatives (rating grades). In level 2, each risk aspects will 
be compared into another and so on for level 3 in each risk category. For level 3 will be compared in accordance with the likelihood and impact toward the five level of risks (very high, high, moderate, low and very low). The final step is resulting eigen value that represent the riskiest aspects/subaspects. The consistency ratio of every pairwise comparison matrix must be lower than $0.1(\mathrm{CR}<0.1)$, if the consistency ratio is greater than 0.1 , the questionnaire must be re-taken as the judgement comes about do not fulfill the requirement.

The assessment is based on the result of the questionnaire filled by 39 experts as the respondents who served as board directors, vice presidents, head of divisions and project leaders of PT.XYZ. For the requirement criteria, a respondent must have a minimum tenure of 5 years in the company and 1 year in the current position also work placed in company's headquarter.

\section{2) AHP Result}

The author is using EXPERT CHOICE 11 Software to help with the calculation, the likelihood and impact value for each aspects and sub-aspects are obtained, as follow:

TABLE XI: RESULT OF AHP

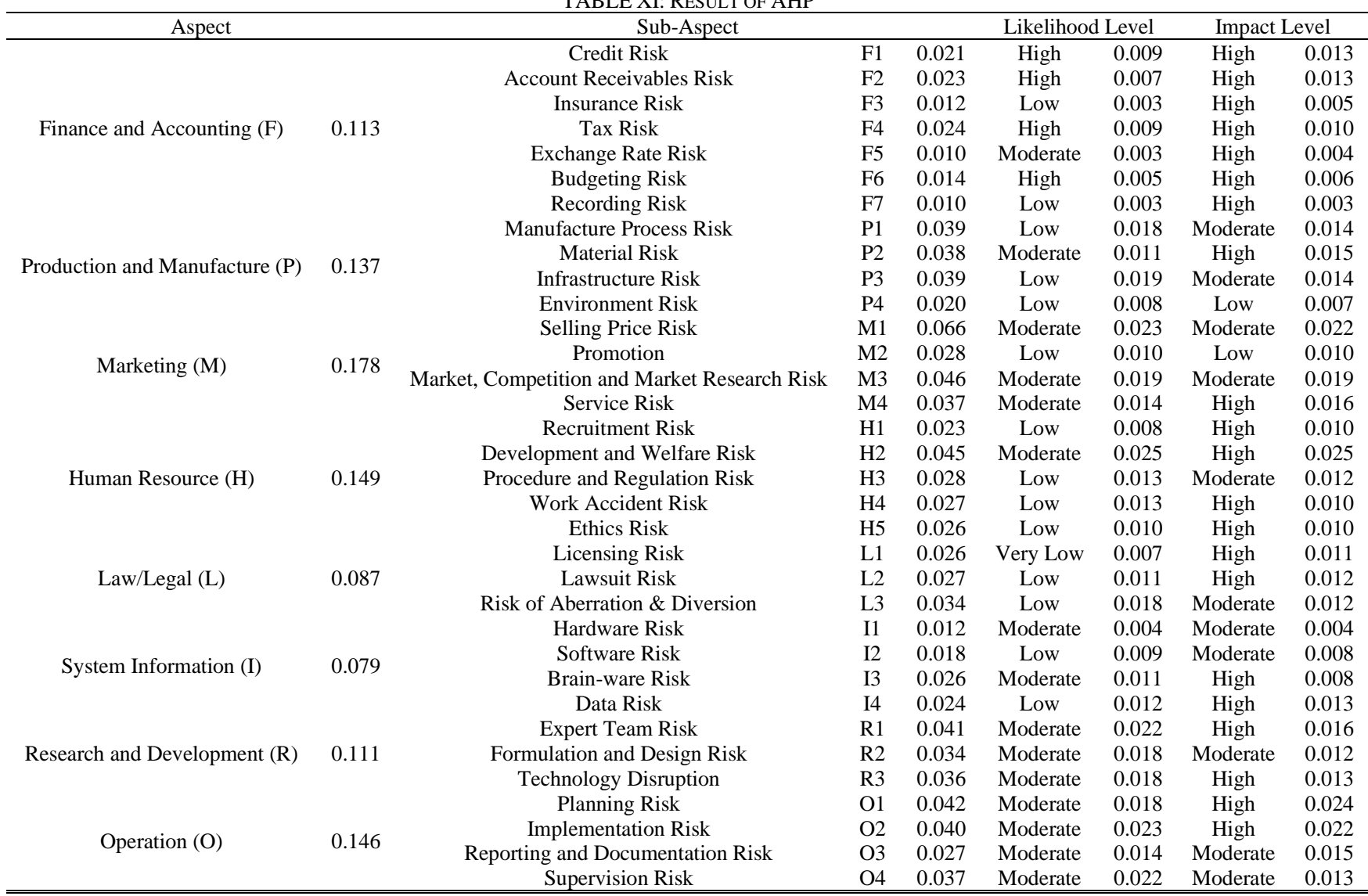

\section{Risk Evaluation/Risk Measurement}

TABLE XII: RISK LEVEL DEFINITION

\begin{tabular}{cl}
\hline \hline Risk Level & \multicolumn{1}{c}{ Definition } \\
\hline Low & $\begin{array}{l}\text { This level of risk can be accepted but still need a regular } \\
\text { monitoring. } \\
\text { This level of risk could be accepted with regular monitoring } \\
\text { for any changes in likelihood or impact levels. Cost-benefit } \\
\text { analysis is required to determine if the risk treatment is } \\
\text { necessary. } \\
\text { This level of risk could not be accepted. Treatment strategies } \\
\text { aimed in order to reduce the risk level should be developed } \\
\text { and implemented immediately. }\end{array}$ \\
High & $\begin{array}{l}\text { On this level of risk need an implementation of immediate } \\
\text { mitigation strategies. the impact of the risk that occur would } \\
\text { be severe that the related activity would need to immediately } \\
\text { ceased. }\end{array}$ \\
\hline \hline
\end{tabular}

Risk Evaluation purpose is to help in making decisions based in the result of risk analysis. It is determine which risks requires a risk treatment as the further action and the priority for treatment implementation [12]. If the risk categorized as the low risk, they might be accepted with minimal risk treatment, but it is still should be monitored and reviewed periodically to ensure that the risk remain acceptable. But, if the risks did not classify as low and acceptable risk, they should be taken a further treatment using one or more of the options considered on the next stage. In order to make a clear sight for management to making decision, we need to developed risk matrix.

Furthermore, each of risk that has been identify will be plotted to the risk matrix to predetermined their risk level definition. Following is the risk mapping result:

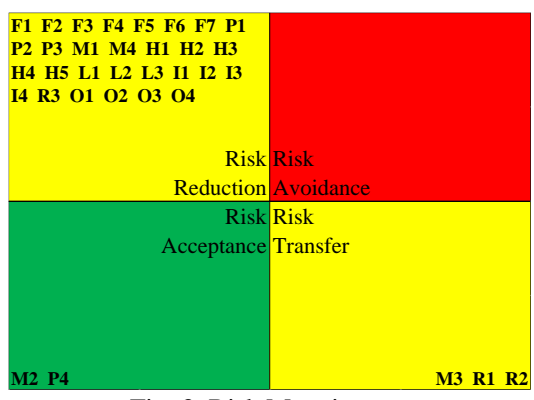

Fig. 3. Risk Mapping. 


\section{E. Risk Treatment/Risk Response}

Risk Treatment including identifying the range of options for risk treatment, assessing those options, prepare for risk treatment planning and implementing them. The treatment alternatives [13]. Selecting the most appropriate risk treatment options involves balancing the cost and effort of implementation against the benefits derived. We can apply the treatment option independently either in combination of several options. On this purpose, the combination of treatment option can give advantage for the company.

Identifying options for risk treatment is the first step need to be conduct in order to develop risk treatment process. There are four types of risk treatment/risk response [16] that describe on the table below:

TABLE XIII: RISK TREATMENT OPTION

\begin{tabular}{lll}
\hline \hline Color Indicator & Level of Risk & Risk Treatment Option \\
\hline & Low & Risk Acceptance \\
Medium & Risk Reduction/Risk Transfer \\
High & Risk Reduction/Risk Transfer \\
& Extreme & Risk Avoidance \\
\hline
\end{tabular}

The second step is assessing the option on the premise of the extent of risk reduction, and the extent of any extra benefit or opportunities created. To choose the most appropriate option need to considering the balance of cost and the benefits if the option is implemented. The best option is an option with a large risk reduction but relatively low cost. If there is an option that has a high risk but the opportunity generated is quite large in the future, for example the application of new technology, then the risk assessment must be based on costs for improvement as a consequence compared to the opportunities resulting from taking the risk. In fact, companies often need to carry out a combination of options for risk treatment, but this has an impact on the amount of costs that must be spent for its implementation beyond the available budget. Then the identification of the priority order of individual risk treatment must be applied. Priority assessment can be carried out by various techniques, one of which is risk ranking and cost-benefit analysis.

The next step is preparing treatment plans. In this section, a selected risk treatment plan must be considered how its implementation. It should identify responsibilities, schedule, treatment expected outcome, budgeting, performance measurement, and review process to be set. And the final step is implementing the treatment plans. Ideally, the obligation for treatment of risk ought to be borne by those best able to control the risk. Obligations ought to concur between the parties at the earliest possible time. The effective implementation of the risk treatment plan requires an effective administration framework which indicates the strategies chosen, assigns obligations and person accountabilities for activities, and monitors them against indicated criteria. If after treatment there is a residual risk, a decision might be taken as to whether to hold this risk or repeat the risk treatment process.

Based on the definition of risk treatment/mitigation and evaluation result, the risk treatment plan for each risk in this research plotted in figure below:

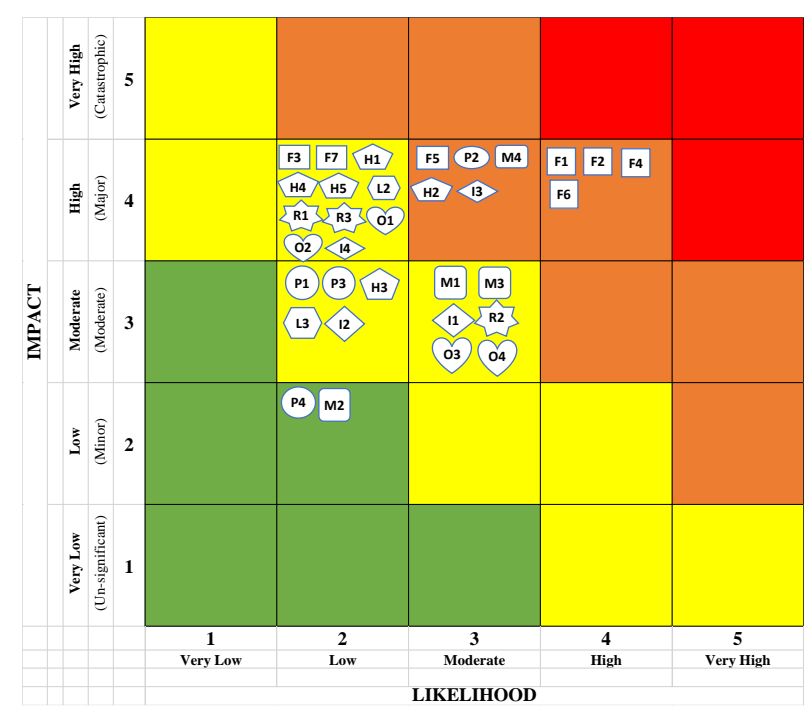

Fig. 3. Risk Treatment Mapping.

\section{F. Risk Monitoring and Review}

After all the steps in the risk management process is carried out, the final stage is the risk monitoring and review. The purpose of risk monitoring and review is to ensure the effectiveness of the risk treatment plan and its implementation. Other than that, it does monitoring is essential to ensure circumstances changes do not alter risk priorities. Variables that may influence the likelihood and impact of the outcome may alter, as may the components which influence the suitability or cost of the different treatment options. It is hence necessary to regularly repeat the risk management cycle. Review is an integral portion of the risk management treatment plan [13].

Monitoring and review can be conducted periodically or ad hoc with expectation to ensure the following points:

1. Effectivity and efficiency in risk control design and operation.

2. Obtain further information for improving risk assessment.

3. Analyze changes, trends, successes, and failure.

4. Detect external and internal changes that can lead into changes in risk criteria and the risk, which required revision of risk treatment and priorities.

5. Identify emerging risks and potential risk that has never been identified before.

6. The form of monitoring and review activities will be presented by timetable in the next chapter with the implementation plan of this research.

\section{SOLUTION AND RECOMMENDATION}

The business issue on this research is the financial condition of PT.XYZ that faced a distress condition which can lead into bankruptcy. In order to identifying what aspect that affect that issue, we conduct the enterprise risk management. Moreover, enterprise risk management can identify which risk aspect should be mitigate to minimize the issue. The recommendation that given in this research based on the result of risk management process. In line with the business issues being faced, that is on the financial aspect, the solutions and recommendations given will focus on the financial aspects as well. And based on the risk mapping, the 
risk that fall under high risk level area, with high likelihood level and high impact level is being a major concern to be mitigate, especially these risks are the fourth most important risk in financial aspect. There are four risk with those condition, as follow:

TABLE XIV: RECOMMENDED RISK TREATMENT PRIORITY

\begin{tabular}{|c|c|c|c|c|}
\hline No. & $\begin{array}{l}\text { Sub- } \\
\text { Aspect }\end{array}$ & $\begin{array}{c}\text { Risk } \\
\text { Level }\end{array}$ & $\begin{array}{c}\text { Risk } \\
\text { Treatment/ } \\
\text { Mitigation }\end{array}$ & Action Plan \\
\hline 1 & $\begin{array}{l}\text { Credit } \\
\text { Risk } \\
(\mathrm{F} 1)\end{array}$ & High & $\begin{array}{c}\text { Risk } \\
\text { Reduction }\end{array}$ & $\begin{array}{l}\text { Debt-to-equity } \\
\text { monitoring by applying } \\
\text { optimum debt-to-equity } \\
\text { ratio analysis, mapping } \\
\text { for alternative funding } \\
\text { sources }\end{array}$ \\
\hline 2 & $\begin{array}{l}\text { Account } \\
\text { Receivab } \\
\text { les Risk } \\
\text { (F2) }\end{array}$ & High & $\begin{array}{c}\text { Risk } \\
\text { Reduction / } \\
\text { transfer }\end{array}$ & $\begin{array}{l}\text { Bad debt reserve, } \\
\text { factoring over the } \\
\text { purchase agreement, } \\
\text { bank guarantees from } \\
\text { letter of credits, trade } \\
\text { credit assurance for } \\
\text { bigger purchase }\end{array}$ \\
\hline 3 & $\begin{array}{l}\text { Tax Risk } \\
\text { (F4) }\end{array}$ & High & $\begin{array}{c}\text { Risk } \\
\text { Reduction }\end{array}$ & $\begin{array}{l}\text { Integrated tax practices } \\
\text { guidelines, external } \\
\text { audit }\end{array}$ \\
\hline 4 & $\begin{array}{l}\text { Budgetin } \\
\text { g Risk } \\
\text { (F6) }\end{array}$ & High & $\begin{array}{c}\text { Risk } \\
\text { Reduction }\end{array}$ & $\begin{array}{l}\text { Scenario analysis, data } \\
\text { validation }\end{array}$ \\
\hline
\end{tabular}

\section{CONCLUSION}

- Based on the result of financial distress analysis using Altman Z-Score model for non-manufacture company in emerging market, PT.XYZ is categorized in distress area in 4 from 2016-2019 with z-score value $-4.49,-2.48,-2.54$, and 4.13 .

- The risk identification process shows eight risk aspects which consist 34 sub-aspects that influence financial condition of PT.XYZ which that: Finance and Accounting (credit risk, account receivables risk, insurance risk, tax risk, exchange rate risk, budgeting risk, recording risk), Production and Manufacture (manufacture process risk, material risk, infrastructure risk, environment risk), Marketing (selling price risk, promotion risk, market, competition and market research risk, service risk), Human Resource (recruitment risk, development and welfare risk, procedure and regulation risk, work accident risk, ethics risk), Law/Legal (licensing risk, lawsuit risk, risk of aberration \& diversion), System Information (hardware risk, software risk, brain-ware risk, data risk), Research and Development (expert team risk, formulation and design risk, technology disruption), and Operation(planning risk, implementation risk, reporting and documentation risk, supervision risk).

- According to eigenvalue the most important risks is marketing aspect. While the least important aspect is system information aspect. And from every aspect the most important sub-aspect is tax risk for finance and accounting aspect, infrastructure risk for production and manufacture aspect, selling price risk for marketing aspect, development and welfare risk for human resource aspect, risk of aberration $\&$ diversion for law/legal aspect, brain-ware risk for system information aspect, expert team risk for research and development aspect and planning risk for operation aspect.

- The eigenvalue from AHP is reflected the importance of each aspect and sub-aspect, however, the risk treatment as the mitigation action are obtained from the likelihood level and impact level. The risk classified into four type of risk level that is low risk, medium risk, high risk and extreme risk which will be mitigated by risk treatment classification: risk acceptance, risk reduction, risk transfer and risk avoidance.

- There is no risk that classified as extreme risk that need to be avoid. The risk that classified into high and medium risk can be mitigate by reduce or transfer the risk depends on the most suitable risk treatment. The sub-aspect that mitigated by risk transfer are manufacture process risk, market competition and market research risk, expert team risk, and formulation and design risk. For the sub-aspect that treated by reducing the risk are credit risk, account receivables risk, insurance risk, tax risk, exchange rate risk, budgeting risk, recording risk, manufacture process risk, material risk, infrastructure risk, selling price risk, service risk, recruitment risk, development and welfare risk, procedure and regulation risk, work accident risk, ethics risk, licensing risk, lawsuit risk, risk of aberration \& diversion, hardware risk, software risk, brain-ware risk, data risk, technology disruption, planning risk, implementation risk, reporting and documentation risk, supervision risk. There are two subaspect that classified as low risk and will be accepted by the company that are: environment risk and promotion risk.

- Based on the analysis, the company need to give extra attention to the risk that have high risk level. So, the implementation plan will be focus on four level categorized as high risk.

\section{REFERENCES}

[1] K. BUMN, "Laporan Kinerja BUMN 2019," BUMN, Kementerian. 2019.

[2] H. Wandebori, Manajemen Strategi Dalam Perspektif Indonesia, 1st ed. Bandung: ITB Press, 2019.

[3] Asosiasi Penyelenggara Jasa Internet Indonesia, "Penetrasi \& Profil Perilaku Pengguna Internet Indonesia," Apjii, p. 51, 2017, [Online]. Available:

https://apjii.or.id/survei2018s/download/TK5oJYBSyd8iqHA2eCh4Fs GELm3ubj.

[4] M. M. Hanafi, Manajemen Keuangan. Yogyakarta: BPFE, 2010.

[5] K. A. Fachrudin, Kesulitan Keuangan Perusahaan dan Personal. Medan: USU Press, 2008.

[6] G. Kunjana, "GCG di BUMN," Investor Daily, 2020. https://investor.id/editorial/gcg-di-bumn (accessed Oct. 19, 2020).

[7] E. I. Altman and E. Hotchkiss, Corporate Financial Distress and Bankruptcy. 2005.

[8] R. W. Saaty, "The analytic hierarchy process-what it is and how it is used," Math. Model., vol. 9, no. 3-5, pp. 161-176, 1987, doi: 10.1016/0270-0255(87)90473-8.

[9] S. Aminbakhsh, M. Gunduz, and R. Sonmez, "Safety risk assessment using analytic hierarchy process (AHP) during planning and budgeting of construction projects," J. Safety Res., vol. 46, pp. 99-105, 2013, doi: 10.1016/j.jsr.2013.05.003.

[10] M. A. Mustafa and J. F. Al-Bahar, "Project Risk Assessment Using the Analytic Hierarchy Process," IEEE Trans. Eng. Manag., vol. 38, no. 1, pp. 46-52, 1991, doi: 10.1109/17.65759.

[11] A. Alkhalidi, S. Tahat, and M. Smadi, "Risk assessment using the analytic hierarchy process while planning and prior to constructing wind projects in Jordan," 2019, doi: 10.1177/0309524X19849862.

[12] ISO 31000, "International Organization for Standardization ISO 31000: Risk management - Principles and guidelines," vol. 2009, p. 36, 2009.

[13] K. Madill, "Standards Australia," 2003.

[14] R. R. Moeller, COSO Enterprise Risk Management (Establishing Effective Governance, Risk, and Compliance Processes, Second edi., vol. 7, no. 2. New Jersey: Wiley Corporate F\&A, 2011.

[15] K. Srinivas, "Process of Risk Management," Perspect. Risk, Assess Manag. Paradig., pp. 1-16, 2019, doi: 10.5772/intechopen.80804.

[16] E. Risk, enterprise risk management (guidance for practical implementation and assessment. New York: American Institute of Certified Public Accountants, Inc. New, 2014. 
APPENDIX

APPENDIX A: COSO SAMPLE TYPES OF ENTERPRISE BUSINESS RISK
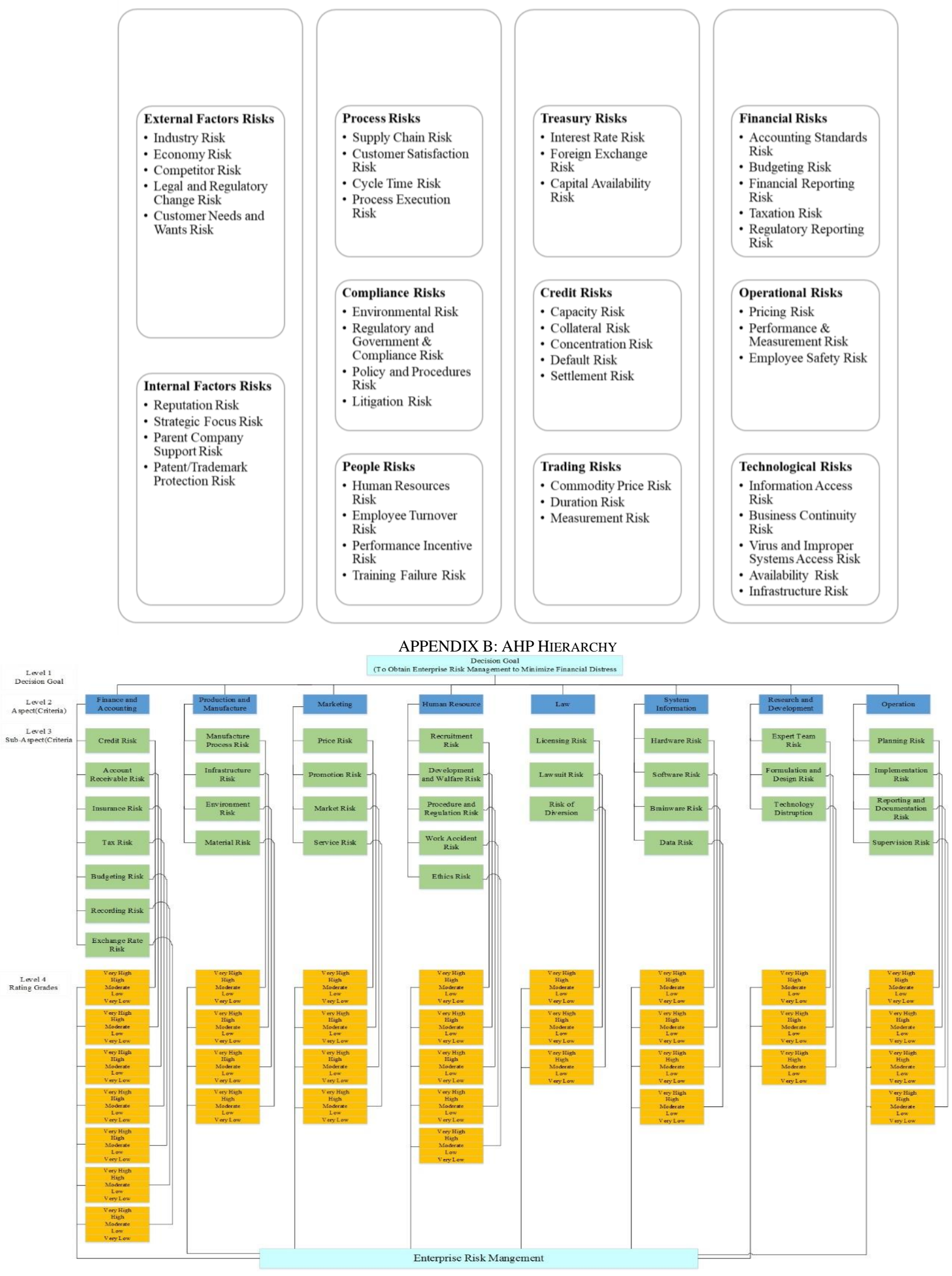
European Journal of Business and Management Research www.ejbmr.org

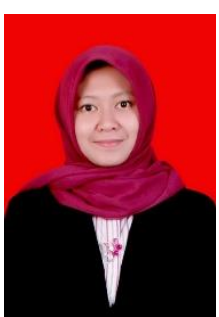

Ervie Nur Afifa Mukhlis S.E., was born in Bandung on September 12, 1994. She got her bachelor degree in Business Management (Finance) from Widyatama University in Bandung 2016. Currently she is pursuing her Master Degree in Business Administration at Institut Teknologi Bandung (ITB). She took Business Risks and Finance as her major for her master degree.

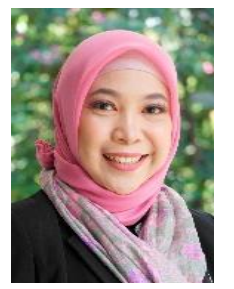

Dr. Sylviana Maya Damayanti, ST., MBA. CFP ${ }^{\circledR}$, CWM ${ }^{\circledR}$, AEPP ${ }^{\circledR}$ earned her Ph.D degree from Faculty of Economics at University of Padjadjaran Bandung in 2015. She obtained her MBA degree from majoring in Management on Institut Teknologi Bandung (ITB) in 2007. And she got her bachelor degree in electrical engineering in Universitas Islam Sultan Agung in 2002.

After she earned her MBA degree, she joined as the lecturer with interest in Business Risks and Finance at School of Business and Management (SBM) ITB. Currently she conducting the Financial Literacy and Inclusion Research Center in SBM ITB partnered with OJK to raise financial literacy and inclusion in Indonesia. 